\title{
Silviano Santiago
}

Universidade Federal do Rio de Janeiro

LS: Quais os conceitos que consideraria mais centrais e fecundos na obra critica e historiográfica de Antonio Candido?

Na vasta e diversificada obra de Antonio Candido, a organicidade na elaboração, divulgação e circulação do aparato conceitual - tanto o crítico quanto o historiográfico - é a principal característica. Nesse sentido, salientar em tal ensaio, ou em tal livro, esse ou aquele conceito predominante seria desfalcá-la do que a torna significativa, original e poderosa no contexto da cultura brasileira e latino-americana.

A imagem que encontro para explicar o jogo entre a saliência persuasiva do detalhe e a totalidade encantadora da organicidade é a do calidoscópio. Os conceitos marcantes - pequenos pedaços coloridos de vidro - são refletidos por espelhos dispostos ao longo da extensa obra, de modo que, quando o leitor a ativa pela leitura sensível e inteligente, enxerga imagens múltiplas em arranjos simétricos.

LS: Neste sentido, que obra ou que ensaio the parece exemplar?

Se vista e apreciada da perspectiva do Autor, tudo é exemplar na obra de Antonio Candido - imagens múltiplas em arranjos simétricos. Espacializo a comparação com o calidoscópio para lembrar a perfeição atingida em quadro de Mondrian.

No entanto, e eis o heroico em termos das sucessivas gerações que se seguiram ao mestre paulista, há que forcejar a entrada crítica alheia numa obra que o tempo e a academia tornaram canônica. Um dia, Mondrian encontra pela frente Josef Albers, Ligia Clark ou Hélio Oiticica.

Os ensaios reunidos em Literatura e sociedade são os que me incitam a resistir à sobrecarga persuasiva da exemplaridade.

Por que são eles que me motivam e me levam a articular a voz própria em sala de aula ou no papel? Lembrar o peso da "desconstrução" em minhas leituras de 
Antonio Candido seria uma resposta fácil, mas certamente consequente. Teria o objeto desconstruído (de maneira mais eloquente: o Autor) sido atento às fraturas expostas? Por não ser cúmplice, fala o silêncio.

LS: A perspectiva de Antonio Candido tem vigência crítica no cenário atual?

Por vir atada a exemplos precisos e gloriosos da criação literária e artística, por estar sendo sempre relativizada por referências à força do pensamento alheio, tanto o nacional quanto o universal, a leitura crítica e historiográfica de Antonio Candido não se encarquilha. Ou melhor, se chega a encarquilhar, é para melhor exibir aos mais jovens a sensatez da experiência vivida - refletida e sonhada. Que vale o lustre da pele escanhoada de rapaz frente aos fios longos e bem aparados da barba senhorial? 